\title{
The Effect of E-Service Quality on Satisfaction and Its Impact on Customer Loyalty of Mobile Banking Users (Case Study of Bank Syariah Mandiri KCP Belawan)
}

\author{
Marliyah $^{1}$, M. Ridwan' ${ }^{2}$ Ayu Kartika Sari ${ }^{3}$ \\ Faculty of Economic and Islamic Bussines, Universitas Islam Negeri Sumatera Utara, Indonesia \\ marliyah@uinsu.ac.id,mridwanku@gmail.com,ayukarsa15@gmail.com
}

\begin{abstract}
Bank Syariah Mandiri (BSM) is a real example of a bank that has utilized information technology as an additional service provided to improve the customer experience in transacting online via the internet, namely through a mobile banking application. The application of mobile banking is one form of BSM's commitment in providing good quality electronic services, and can be felt and assessed by customers who have used it. These assessments can then affect their level of satisfaction. Based on this, it then encouraged researchers to test the influence of the quality of mobile banking electronic services offered by Bank Syariah Mandiri KCP Belawan on the satisfaction and loyalty of mobile banking users. This research is intended to analyze the effect of $e$ service quality on customer satisfaction and its impact on customer loyalty. Questionnaire items used as many as 35 items. Data collection is done by distributing questionnaires to customers of Bank Syariah Mandiri KCP Belawan who at least have an account and use BSM mobile banking application for 3 (three) months with a sample number of 84 people determined by nonprobability sampling method. The analytical technique used is Structural Equation Modeling Partial Least Square (SEM-PLS). The results obtained in this study are that: (1) The relationship of e-service quality has a positive and significant effect on customer satisfaction. This can be proven from the t-value greater than 1.96 which is 13,230. Thus, HI in this study was accepted. (2) The relationship of e-service quality has a positive and significant effect on customer loyalty. This can be proven from the $t$-value greater than 1.96 which is 3,267. Thus, H2 in this study was accepted. (3) Customer satisfaction relationship has a positive and significant effect on customer loyalty. This can be proven from the $t$-value greater than 1.96 which is 3,666. Thus, H3 in this study was accepted.
\end{abstract}

Keywords e-service quality, customer satisfaction; customer loyalty

\section{Introduction}

Loyalty is needed by companies because without loyalty, the company will find it difficult to grow and develop properly (Rakhmat Romadhan, et. Al, 2019). According to Griffin, consumer loyalty has more to do with attitude than with behavior. If the customer is loyal, he will show a buying attitude which is defined as a buyer who is repeated from time to time by several decision-making factors (Jill Griffin, 2010). Customer loyalty can occur after the customer is satisfied, and customers will feel satisfied if they get the best service quality (Rizal Zulkarnain, et. Al, 2020). This is supported by I Gusti's statement, that the need for good service quality from the company in order to create a good satisfaction. According to Lewis \& Booms in Tjiptono \& Chandra, in the service quality approach there are 5 (five) 
dimensions to measure the level of satisfaction, one of which is tangibles (direct evidence), which is the size of the ability of one party to provide services to external parties (Fandy Tjiptono and Gregorius Chandra, 2011). According to Argawijana, satisfied consumers will recommend to others for what they feel (Argawijana, et al, 2020).

Mobile banking services are service products that can facilitate and accelerate customers in making transactions, services that can be done electronically without having to go to a bank to make transactions (Financial Services Authority (OJK), 2020). To get a lot of consumers, one way to do this is to create customer loyalty (Harahap, 2021). Service quality and innovation are two elements that can build competitive advantage, because the quality of service as a infrastructure that is adequate in providing services, while innovation is applied because consumers want a renewal in the services perceived by consumers, so the end result of service quality and innovation is the creation of competitive advantage (Kusumadewi, 2019). Bank Syariah Mandiri, Belawan Branch, which is part of the operational activities of Bank Syariah Mandiri also implements digital banking as a form of service to customers, such as opening new accounts online using mobile banking for opening savings accounts, cash transactions and online interbank transfers with features that include: very good (PT Bank Syariah Mandiri, 2020). However, there are still many customers who complain about the use of Mobile Banking at Bank Syariah Mandiri.

Table 1. Recapitulation of the Number of Complaints from Mobile Banking User Customers

Bank Syariah Mandiri Period 2017-2019

\begin{tabular}{|c|c|c|c|}
\hline \multirow{2}{*}{ Description } & \multicolumn{3}{|c|}{ Year } \\
\cline { 2 - 4 } & $\mathbf{2 0 1 7}$ & $\mathbf{2 0 1 8}$ & $\mathbf{2 0 1 9}$ \\
\hline TW I & 1,417 & 4,446 & 2,343 \\
\hline TW II & 1,430 & 1,329 & 2.002 \\
\hline TW III & 4,003 & 1,635 & 1,917 \\
\hline TW IV & 7,925 & 2,082 & 4,130 \\
\hline Amount & $\mathbf{1 4 , 7 7 5}$ & $\mathbf{9 , 4 9 2}$ & $\mathbf{1 0 , 3 9 2}$ \\
\hline
\end{tabular}

Source: Bank Syariah Mandiri Annual Report 2017, 2018, and 2019

Table 1 describes that the highest number of customer complaints from Bank Syariah Mandiri car banking users was in 2017 and subsequently decreased in 2018 and rose again in 2019. With regard to customer service, currently the concept of e-service quality is a form of service that is given to customers. E-Service Quality is a service by utilizing digital electronic technology or utilizing the internet as an effort to facilitate customers in making transactions and utilizing bank services. The concept of e-service quality consists of several elements that support it, namely Site Usability, Quality of Information displayed, Reliability, Responsiveness, Assurance and Personalization (Fandy, Tjiptono, 2016).

The formulations of the problems studied in this study are:

1. How is the direct effect of e-service quality on customer loyalty of mobile banking users at Bank Syariah Mandiri KCP Belawan?

2. How does the existence of e-service quality affect the customer satisfaction of mobile banking users at Bank Syariah Mandiri KCP Belawan?

3. How is the effect of e-service quality on customer loyalty through the variable customer satisfaction of mobile banking users at Bank Syariah Mandiri KCP Belawan? 


\section{Review of Literatures}

The mobile banking service is a development of the two previous forms of innovation, namely sms banking and internet banking. Both forms of banking information technology are internet-based (Muammar Arafat Yusmad, 2018). Audi et al., Mobile banking can be defined as a banking channel where consumers / customers or account holders can use their cell phones to carry out banking transactions or other financial services related to or interact with the bank (Audi, M. F, et al, 2016). Syamsul Hadi, the easier a system is to learn and use, it will increase customer interest in using mobile banking (Syamsul Hadi, 2015).

Rowley in Fretty Welta, e-service is an act, effort or show whose delivery is mediated by information technology (Fretty Welta, 2017). E-service is viewed as content that is interactive, centralized and internet-based, thus giving birth to a new version of service quality known as eservice quality (D. Napitupulu, 2016).

According to Swaid and Wigand, to measure the results of e-service quality, there are 6 (six) dimensions that stand out the most, namely:

1. Website Usability. Website usability is a consumer's perception of the level of ease in using the website / application and navigation, as well as a website / application that is visually attractive and well designed. Indicators that explain the usefulness of the site / application are: 1) Effective (website / application search function), 2) Efficient (Time to process transactions), 3) Simple system menu, 4) Website / Application has an attractive appearance, 5) Innovative (Characteristics typical website / application design), 6) Creative (Ideas from the form of website / application design), 7) Website / application design layouts are organized quickly and regularly, 8) Website / application design layouts are neatly and orderly

2. Information Quality (Information Quality), the quality of information includes the accuracy and accuracy of information provided to consumers. The quality of information can be measured by the following indicators: 1) The accuracy of the information provided, 2) The correctness of the information can be trusted, 3) Information is always up to date, 4) The information is in accordance with the theme of the website / application, 5) Information that is easily accessible understand, 6) Information in the form of a guide

3. Reliability (Reliability), Reliability basically refers to the consumer's perception of the reliability of the site and the accuracy of the services promised to consumers. For example, confirmation emails regarding bills and information on goods or services offered. To measure reliability, several indicators are used, namely: 1) Mobile banking processes transactions right away. 2) Mobile banking processes transactions correctly 3) Mobile banking is the best way to make transactions, 4) Mobile banking does not make mistakes in processing transactions, 5) Mobile banking can be used at any time

4. Responsiveness, responsiveness in e-service is the perception of consumers to get responses or help quickly when they have a problem or question. To measure responsiveness using the following indicators: 1) Mobile banking provides problem solutions, 2) Mobile banking response when processing transactions 3) Mobile banking helps make transactions quickly

5. Guarantee (Assurance), Guarantee includes the trust that consumers feel in dealing with the website / application in accordance with the reputation of the application and the goods or services sold, as well as the clarity and accuracy of the information provided. To measure the guarantee using the following indicators, namely: 1) Term and condition policy can be accessed, 2) There is a security system, 3) There is a contact number or call center, 4) The bank that owns the mobile banking has a good reputation 
6. Personalization (Personalization), Personalization in e-services includes how much and how easy a website / application can be personalized to meet consumer needs according to their respective preferences (Swaid, SI, \& Wigand, R. T, 2009). To measure personalization, the following indicators are used, namely: 1) Providing information about transactions, 2) How to make transactions according to customer needs, 3) Products and services offered are tailored to specific customer needs

Furthermore, Kotler defines satisfaction as a feeling of pleasure or disappointment in a person that arises after comparing the product's perceived performance (or results) against the expected (P. Kotler and Keller, K. L, 2012). Lupiyoadi stated that customer loyalty is understood as a combination of customer's favorable attitude and repurchase behavior (R. Lupiyoadi, 2013).

\section{Research Methods}

This research is a quantitative research with a survey. This research was conducted at Bank Syariah Mandiri KCP Belawan which is located at Jalan Sumatra, Belawan I, Medan City, and North Sumatra. The research population is the customers of mobile banking usersBank Syariah Mandiri KCP Belawan Year 2020.

Table 2. Number of Bank Syariah Mandiri KCP Belawan Mobile Banking Users

\begin{tabular}{|c|c|c|}
\hline \multicolumn{3}{|c|}{2020 year } \\
\hline No. & Month & $\begin{array}{c}\text { Number of Users } \\
\mathbf{2 0 2 0}\end{array}$ \\
\hline 1 & February & 45 \\
\hline 2 & March & 31 \\
\hline 3 & April & 20 \\
\hline 4 & May & 10 \\
\hline \multicolumn{2}{|c|}{ amount } & $\mathbf{1 0 6}$ \\
\hline
\end{tabular}

Source: Bank Syariah Mandiri KCP Belawan

So that the research population is 106 respondents. The technique for determining the number of samples in this study uses the Slovin formula as follows:

$$
\begin{aligned}
& n=\frac{106}{1+106(0,05)^{2}}=83.79 \text { customers } \\
& \quad n=83.79 \text { customers }=84 \text { customers (rounded) }
\end{aligned}
$$

Based on the sample calculation, obtained $n=84$ respondents. The determination technique used is the purposive sampling technique. The main criteria for selecting the sample in this study are customers who have 3 (three) months of having an account and using the mobile banking application. In this case the researcher immediately provides a list of questions / questionnaires to customers who use mobile banking at the KCP Belawan Sharia Bank. The data analysis technique used is the Component Based Structure Equation Model (SEM) with the Smart PLS program. 


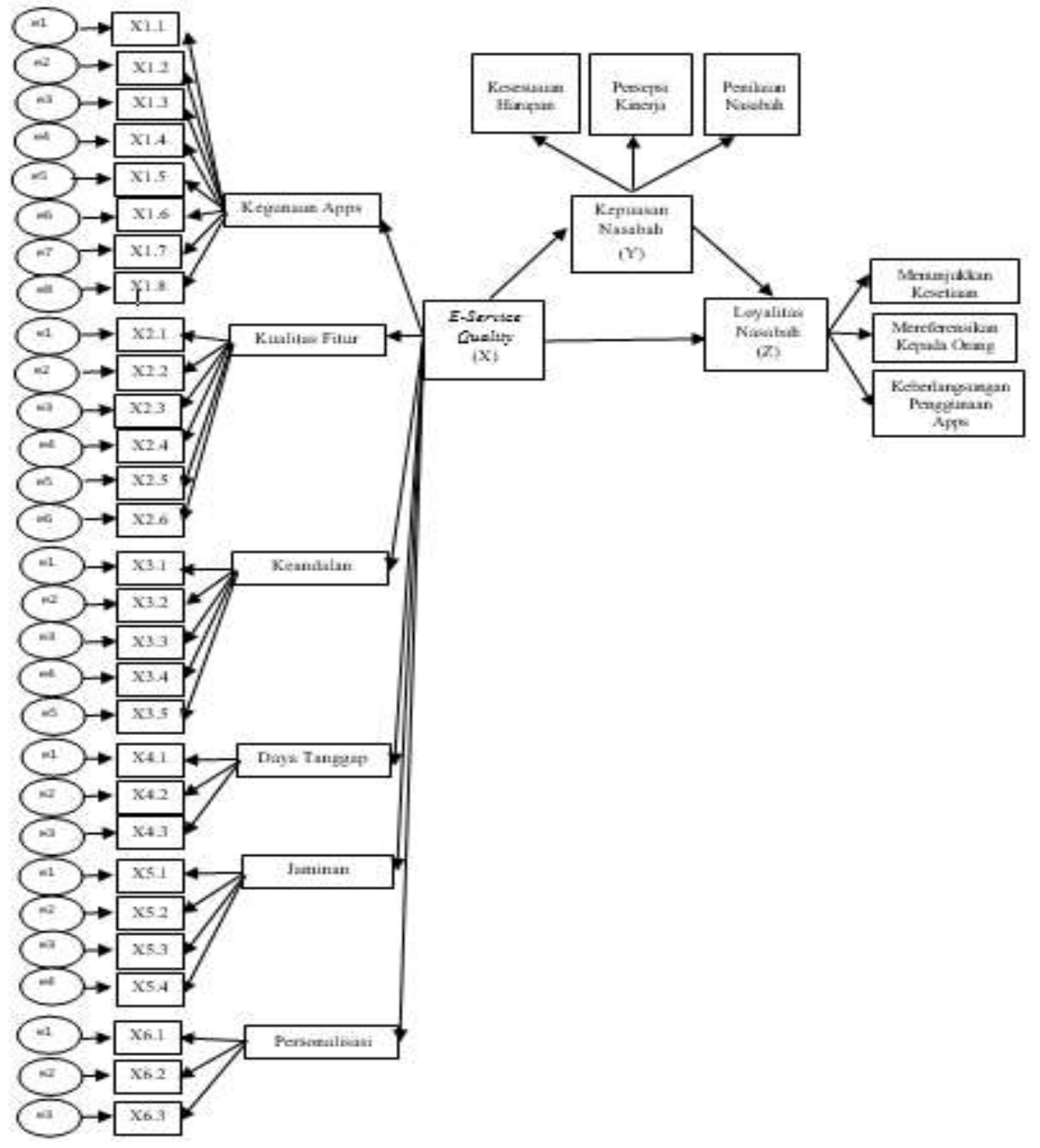

Figure 1. Structural Equation Modeling (SEM)

\section{Results and Discussion}

\subsection{Results}

\section{a. Structural Analysis of Equation Modeling With Smart PLS}

In the PLS-SEM analysis, it consists of two sub-models, namely the measurement model or the outer model and the structural model or the inner model.

\section{b. Evaluation of the Measurement Model (Outer Model)}

Outer models with reflective indicators were evaluated through convergent validity and discriminant as well as composite reliability and Cronbach alpha.

\section{Convergent Validity}

Convergent validity test with reflective indicators can be seen from the loading factor value for each construct indicator with the expected value of 0.7 . For the average variance extracted (AVE) value must be> 0.5. However, for research in the early stages of developing a measurement scale, a loading factor value of 0.5-0.6 is still considered sufficient (Imam Ghozali, et al. 2015). 
Table 3. Outer Loading

\begin{tabular}{|c|c|c|c|}
\hline & $\begin{array}{c}\text { Electronic Service } \\
\text { Quality }(\mathbf{X})\end{array}$ & $\begin{array}{c}\text { Customer } \\
\text { Satisfaction (Y) }\end{array}$ & $\begin{array}{c}\text { Customer } \\
\text { Loyalty (Z) }\end{array}$ \\
\hline \multicolumn{4}{|l|}{$\begin{array}{c}\text { Electronic Service } \\
\text { Quality }(\mathbf{X})\end{array}$} \\
\hline ESQ_01 & 0.829 & & \\
\hline ESQ_02 & 0.774 & & \\
\hline ESQ_03 & 0.809 & & \\
\hline ESQ_04 & 0.707 & & \\
\hline ESQ_05 & 0.724 & & \\
\hline ESQ_06 & 0.773 & & \\
\hline ESQ_07 & 0.794 & & \\
\hline ESQ_08 & 0.723 & & \\
\hline ESQ_09 & 0.804 & & \\
\hline ESQ_10 & 0.831 & & \\
\hline ESQ_11 & 0.760 & & \\
\hline ESQ_12 & 0.760 & & \\
\hline ESQ_13 & 0.799 & & \\
\hline ESQ_14 & 0.816 & & \\
\hline ESQ_15 & 0.791 & & \\
\hline ESQ_16 & 0.768 & & \\
\hline ESQ_17 & 0.833 & & \\
\hline ESQ_18 & 0.845 & & \\
\hline ESQ_19 & 0.822 & & \\
\hline ESQ_20 & 0.829 & & \\
\hline ESQ_21 & 0.861 & & \\
\hline ESQ_22 & 0.838 & & \\
\hline ESQ_23 & 0.777 & & \\
\hline ESQ_24 & 0.830 & & \\
\hline ESQ_25 & 0.784 & & \\
\hline ESQ_26 & 0.854 & & \\
\hline ESQ_27 & 0.709 & & \\
\hline ESQ_28 & 0.851 & & \\
\hline ESQ_29 & 0.761 & & \\
\hline \multicolumn{4}{|l|}{$\begin{array}{c}\text { Satisfaction } \\
\text { Customer (Y) }\end{array}$} \\
\hline KEP_1 & & 0.900 & \\
\hline KEP_2 & & 0.915 & \\
\hline KEP_3 & & 0.948 & \\
\hline \multicolumn{4}{|l|}{$\begin{array}{c}\text { Loyalty } \\
\text { Customer (Z) }\end{array}$} \\
\hline LOY_1 & & & 0.886 \\
\hline LOY_2 & & & 0.925 \\
\hline LOY 3 & & & 0.915 \\
\hline
\end{tabular}

Source: Primary data processed with SmartPLS 3.0

Based on Table 3 above, it can be seen that the value outer loading of each indicator in the e-service quality variable $(\mathrm{X})$, customer satisfaction $(\mathrm{Y})$, and customer loyalty $(\mathrm{Z})$ all have values> 0.6. This means that the indicators used in this study have metconvergent validity. 
Table 4. Average Variance Extracted (AVE)

\begin{tabular}{|l|c|}
\hline & $\begin{array}{c}\text { Average Variance } \\
\text { Extracted (AVE) }\end{array}$ \\
\hline Electronic Service Quality & 0.634 \\
\hline Customer Satisfaction & 0.849 \\
\hline Customer Loyalty & 0.826 \\
\hline
\end{tabular}

Source: Primary data processed with SmartPLS 3.0

Based on table 4, it can be seen that the AVE value of the variable e-service quality $(\mathrm{X})$, customer satisfaction $(\mathrm{Y})$, and customer loyalty $(\mathrm{Z})$ is $>0.5$. Thus, all of the research variables are valid.

\section{Discriminant Validity}

Discrimianant validity test by looking at the cross loading value to find out whether the construct has sufficient discriminant. The cross loading value for each variable must be> 0.7 .

Table 5. Cross Loading

\begin{tabular}{|l|c|c|c|}
\hline & $\begin{array}{c}\text { Electronic } \\
\text { Service Quality }\end{array}$ & $\begin{array}{c}\text { Customer } \\
\text { Satisfaction }\end{array}$ & $\begin{array}{c}\text { Customer } \\
\text { Loyalty }\end{array}$ \\
\hline ESQ_01 & 0.829 & 0.671 & 0.729 \\
\hline ESQ_02 & 0.774 & 0.610 & 0.683 \\
\hline ESQ_03 & 0.809 & 0.683 & 0.625 \\
\hline ESQ_04 & 0.707 & 0.661 & 0.637 \\
\hline ESQ_05 & 0.724 & 0.597 & 0.535 \\
\hline ESQ_06 & 0.773 & 0.737 & 0.677 \\
\hline ESQ_07 & 0.794 & 0.679 & 0.599 \\
\hline ESQ_08 & 0.723 & 0.648 & 0.594 \\
\hline ESQ_09 & 0.804 & 0.651 & 0.716 \\
\hline ESQ_10 & 0.831 & 0.646 & 0.677 \\
\hline ESQ_11 & 0.760 & 0.562 & 0.567 \\
\hline ESQ_12 & 0.760 & 0.756 & 0.691 \\
\hline ESQ_13 & 0.799 & 0.612 & 0.642 \\
\hline ESQ_14 & 0.816 & 0.705 & 0.739 \\
\hline ESQ_15 & 0.791 & 0.567 & 0.702 \\
\hline ESQ_16 & 0.768 & 0.533 & 0.607 \\
\hline ESQ_17 & 0.833 & 0.596 & 0.676 \\
\hline ESQ_18 & 0.845 & 0.657 & 0.675 \\
\hline ESQ_19 & 0.822 & 0.624 & 0.601 \\
\hline ESQ_20 & 0.829 & 0.675 & 0.726 \\
\hline ESQ_21 & 0.861 & 0,700 & 0.724 \\
\hline ESQ_22 & 0.838 & 0.695 & 0.723 \\
\hline ESQ_23 & 0.777 & 0.638 & 0.617 \\
\hline ESQ_24 & 0.830 & 0.737 & 0.752 \\
\hline ESQ_25 & 0.784 & 0.638 & 0.698 \\
\hline ESQ_26 & 0.854 & 0.706 & 0.752 \\
\hline ESQ_27 & 0.709 & 0.685 & 0.673 \\
\hline & & & \\
\hline & & & 0.96 \\
\hline
\end{tabular}




\begin{tabular}{|l|l|l|l|}
\hline ESQ_28 & 0.851 & 0.668 & 0.683 \\
\hline ESQ_29 & 0.761 & 0.791 & 0.824 \\
\hline KEP_1 & 0.714 & 0.900 & 0.766 \\
\hline KEP_2 & 0.778 & 0.915 & 0.733 \\
\hline KEP_3 & 0.808 & 0.948 & 0.877 \\
\hline LOY_1 & 0.789 & 0.814 & 0.886 \\
\hline LOY_2 & 0.773 & 0.796 & 0.925 \\
\hline LOY_3 & 0.758 & 0.737 & 0.915 \\
\hline
\end{tabular}

Source: Primary data processed with SmartPLS 3.0

Based on Table 5 above, it shows that the latent constructs with the indicators on their block are better or have a higher value than the indicators in other blocks which have lower values, with the cross loading value of each construct having a value> 0.7 which means that the construct have sufficient discriminant.

\section{Reability}

The reliability test is carried out to prove the accuracy, consistency and accuracy of the instruments in measuring constructs. The reliability of a construct can be done in 2 (two) ways, namely Cronbach's alpha and composite reliability. The construct is declared reliable if the value of Cronbach's alpha or composite reliability is $>0.7$.

Table 6. Cronbach's Alpha

\begin{tabular}{|l|c|c|}
\hline \multirow{2}{*}{\begin{tabular}{c}
\multirow{2}{*}{$\begin{array}{c}\text { Construct / } \\
\text { Variable }\end{array}$} \\
\cline { 2 - 3 }
\end{tabular}} & $\begin{array}{c}\text { Reability } \\
\text { Cronbach's } \\
\text { Alpha }\end{array}$ & $\begin{array}{c}\text { Composite } \\
\text { Reliability }\end{array}$ \\
\hline Electronic Service Quality (X) & 0.979 & 0.980 \\
\hline Customer Satisfaction (Y) & 0.911 & 0.944 \\
\hline Customer Loyalty (Z) & 0.894 & 0.934 \\
\hline
\end{tabular}

Source: Primary data processed with SmartPLS 3.0

Based on Table 6 above, it shows that the Croncbach's alpha value of each variable is> 0.7 , while the composite reliability value of each variable is also $>0.7$. Thus it can be concluded that each variable has met the reliability criteria and has a high level of reliability.

\section{c. Evaluation of the Structural Model (Inner Model)}

Aims to predict the relationship between latent variables. The inner model is evaluated by looking at the R-Square value. Furthermore, evaluation of the model by looking at the significance value (hypothesis testing) to determine the effect between variables through the bootstrapping procedure. Based on the PLS output, the following image is obtained: 


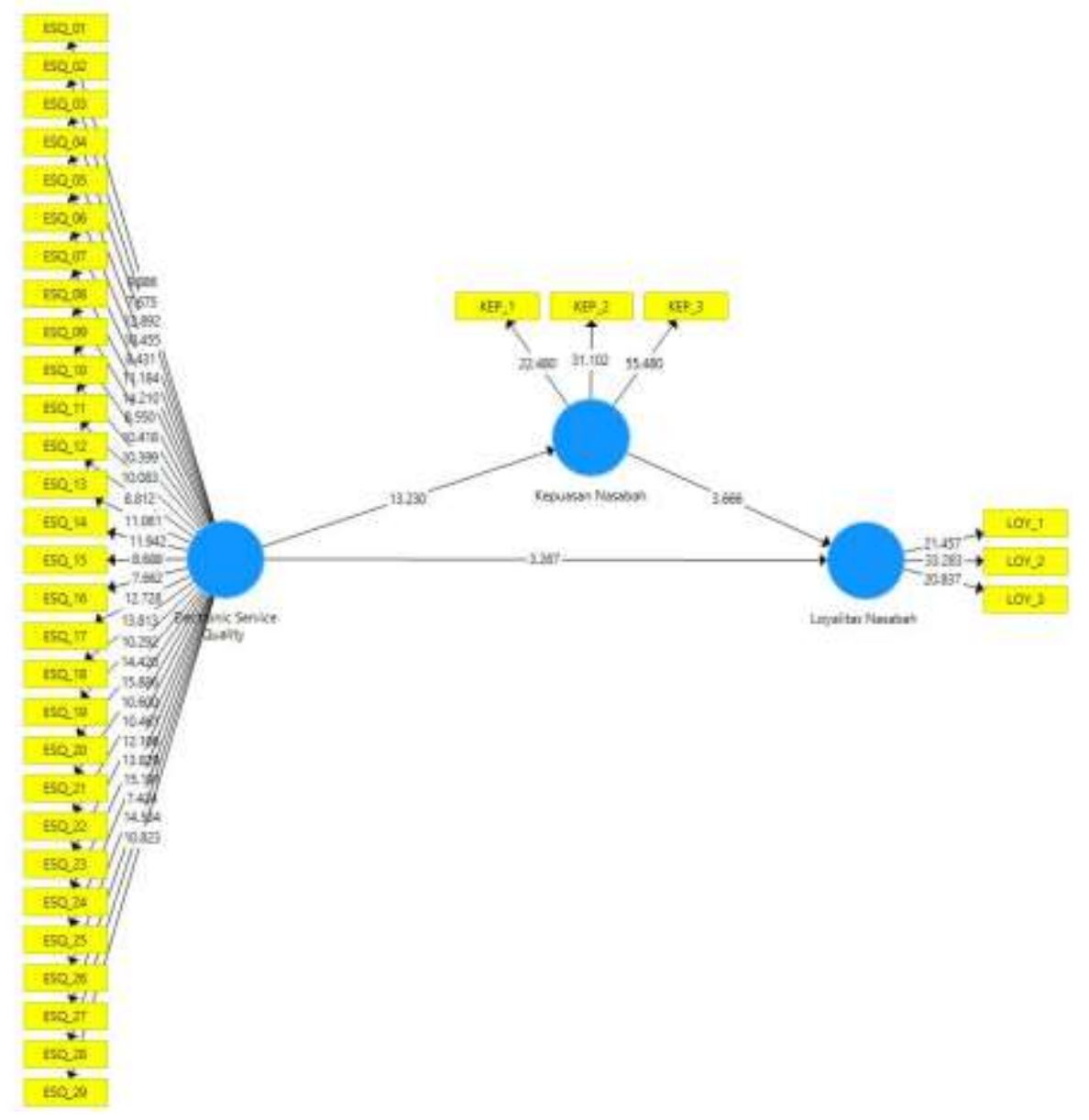

Figure 2. Structural Model (Inner Model)

1) R-Square

The R-Square value is used to explain the effect of certain exogenous latent variables on endogenous latent variables whether they have a substantive effect. The value categories of $0.75,0.50$ and 0.25 indicate the model (strong, moderate and weak).

Table 7. $R$-Square

\begin{tabular}{|l|c|c|}
\hline & $\boldsymbol{R}$ Square & $\boldsymbol{R}$ Square Adjusted \\
\hline $\begin{array}{l}\text { Customer Satisfaction } \\
\text { (Y) }\end{array}$ & 0.695 & 0.691 \\
\hline Customer Loyalty (Z) & 0.802 & 0.797 \\
\hline
\end{tabular}

Source: Primary data processed with SmartPLS 3.0

Based on Table 7 above, it shows that the R-Square value for the customer satisfaction variable (Y) is 0.695 which means it is included in the moderate category. Furthermore, the $\mathrm{R}$-Square value for the customer loyalty variable $(\mathrm{Z})$ is 0.802 which means it is included in the strong category. 


\section{d. Hypothesis Test}

1. Path Coefficient

This test is carried out by looking at the significance to determine the effect between variables through the bootstrapping procedure. The significance value can be done by looking at the parameter coefficient and the T-statistic on the path coefficient. The research hypothesis is accepted if the T-statistic value is $>1.96$ ( $\mathrm{t}$ table of $5 \%$ significance).

Table 8. Path Coefficient

\begin{tabular}{|l|c|c|c|c|c|}
\hline & $\begin{array}{c}\text { Original } \\
\text { Sample } \\
(\mathbf{O})\end{array}$ & $\begin{array}{c}\text { Sample } \\
\text { Mean } \\
(\mathbf{M})\end{array}$ & $\begin{array}{c}\text { Standard } \\
\text { Deviation } \\
\text { (STDEV) }\end{array}$ & $\begin{array}{c}\text { T Statistics ( } \\
\text { O / STDEV } \\
\text { () }\end{array}$ & P Values \\
\hline $\begin{array}{l}\text { Electronic Service } \\
\text { Quality -> Customer } \\
\text { Satisfaction }\end{array}$ & 0.834 & 0.825 & 0.063 & 13,230 & $\mathbf{0 , 0 0 0}$ \\
\hline $\begin{array}{l}\text { Electronic Service } \\
\text { Quality -> Customer } \\
\text { Loyalty }\end{array}$ & 0.436 & 0.444 & 0.134 & 3,267 & $\mathbf{0 . 0 0 1}$ \\
\hline $\begin{array}{l}\text { Customer Satisfaction } \\
\text {-> Customer Loyalty }\end{array}$ & 0.499 & 0.487 & 0.136 & 3,666 & $\mathbf{0 , 0 0 0}$ \\
\hline
\end{tabular}

Source: Primary data processed with SmartPLS 3.0

Based on the results of the path coefficient above, it can be seen that first, the e-service quality (X) variable on the customer satisfaction variable (Y) produces a parameter coefficient value of 0.834 with a T-Statistical value of 13.230 which is greater than (T Table 1.96) and $P$ values of 0.000 are smaller than (significance level 0.5 ). Thus, it means that the e-service quality $(\mathrm{X})$ variable affects the customer satisfaction variable $(\mathrm{Y})$, so that the H1 hypothesis can be accepted.

Second, the variable e-service quality $(\mathrm{X})$ on the customer loyalty variable $(\mathrm{Z})$ produces a parameter coefficient value of 0.436 with a T-Static value of 3.267 which is greater than ( $\mathrm{T}$ Table 1.96) and $P$ Values of 0.001 which is smaller than (significance level 0.5). Thus, it means that the e-service quality $(\mathrm{X})$ variable affects the customer loyalty variable $(\mathrm{Z})$, so that the $\mathrm{H} 2$ hypothesis can be stated as accepted.

Third, the customer satisfaction variable (Y), the customer loyalty variable (Z) produces a parameter coefficient value of 0.499 with a T-Static value of 3.666 which is greater than (T Table 1.96) and P Values of 0.000 which is smaller than ( significance level of 0.5 ). Thus, it means that the customer satisfaction variable (Y) affects the customer loyalty variable $(Z)$, so that the hypothesis $\mathrm{H} 3$ can be stated as accepted.

\subsection{Discussion}

\section{a. The Effect of E-Service Quality on Customer Satisfaction}

Based on the results of hypothesis testing, it can be concluded that the E-Service Quality variable has a significant effect on the Customer Satisfaction variable of Bank Syariah Mandiri KCP Belawan mobile banking users which can be seen from the t-statistic value of 13.230 is more than the $t$-table value, which is 1.96 , which means that it has a significant effect with a path coefficient of 0.834 which means it has a positive effect.. Thus the hypothesis (H1) in this study is accepted.

The results of this study are in line with those conducted by Ni Made Savitri Anggraeni and Ni Nyoman Kerti Yasa in the Journal of Finance and Banking (2012), with the research title "The Effect of E-Service Quality on Customer Satisfaction and Loyalty in Internet Banking Users (Case Study at Commonwealth Bank Seminyak Bali Branch)" which states 
that e-service quality positive and significant effect on satisfaction, e-service quality is positive and significant on loyalty, satisfaction has a positive and significant effect on customer loyalty in using internet banking.

This is in accordance with the opinion expressed by Zeithaml in Anshoer, e-service quality is the extent to which a website / application can facilitate customers effectively and efficiently in purchasing products or services, purchasing and even delivery of products or services. The importance of providing quality service is because service is not limited to delivering or serving. Service means understanding, understanding, and feeling so that the delivery will also be about heart service which in turn will strengthen the position in the mind share of consumers or customers.

\section{b. The Effect of E-Service Quaity on Customer Loyalty}

Based on the results of hypothesis testing, it can be concluded that the E-Service Quality variable has an effect on the Customer Loyalty variable for Mobile Banking users of Bank Syariah Mandiri KCP Belawan which can be seen from the t-statistic value of 3.267 is more than the t-table value which is 1.96 which means that it has a significant effect with a path coefficient of 0.436 which means it has a positive effect.. Thus the hypothesis (H2) in this study is accepted.

The results of this study are in line with the research conducted by David in the AGORA Journal (2018), with the research title "The Effect of E-Service Quality on Customer Loyalty through Customer Satisfaction in Grab Online Transportation" which states that e-service quality has a positive and significant effect on customer satisfaction, customer satisfaction has a positive and significant effect on customer loyalty, and e-service quality positive and significant effect on customer loyalty.

This is in accordance with the opinion expressed by Kotler and Keller that customer / consumer satisfaction is a very determining factor for the image of a company because customer / consumer disappointment in receiving a service from the company will make it difficult for the company to grow and develop, so that customers / consumers can be maintained, of course, must be given maximum service in accordance with their expectations. With regard to providing customer service, Islam has also arranged how to produce quality services for its customers. Achieving the best service quality in an organization or company requires a solid foundation of Islamic management building or also known as "Total Islam Quality (TIQ)", where the foundation of the building comes from the Al-Quran and Hadith.

\section{c. Effect of Customer Satisfaction on Customer Loyalty}

Based on the results of hypothesis testing, it can be concluded that the Customer Satisfaction variable has an effect on the Customer Loyalty variable for Mobile Banking users of Bank Syariah Mandiri KCP Belawan which can be seen from the t-statistic value of 3.666 is more than the t-table value which is 1.96 which means that it has a significant effect with a path coefficient of 0.499 which means that it has a positive effect.. Thus the hypothesis (H3) in this study is accepted.

The results of this study are in line with research conducted by Felicia Laurent in the AGORA Journal (2016)with the research title "The Effect of E-Service Quality on Go-Jek Customer Loyalty through Customer Satisfaction". The results this research state thateservice quality positive effect on customer loyalty through customer satisfaction.

This is in accordance with the opinion expressed by Tjiptono that customer loyalty is a customer commitment to a product or service based on positive characteristics in long-term purchases. Loyalty in Islam is called al-wala '. Customer loyalty in Islam occurs when muamalah activities can provide mutually beneficial benefits for both parties, because of the fulfillment of each other's obligations and rights through the application of Islamic values. 


\section{Conclusion}

This study aims to determine whether e-service quality affects customer loyalty with customer satisfaction as a moderating variable. Based on the empirical testing that has been carried out on the hypothesis in the study, the results show that all the independent variables above have a significant effect on the dependent variable. Based on the results of statistical calculations in this study, it can be concluded that:

1. There is a direct influence of the e-service quality variable on the customer satisfaction of Bank Syariah Mandiri KCP Belawan mobile banking users.

2. There is a direct influence of the e-service quality variable on customer loyalty of Bank Syariah Mandiri KCP Belawan mobile banking users.

3. There is a direct influence of the customer satisfaction variable on the customer loyalty of Bank Syariah Mandiri KCP Belawan mobile banking users.

\section{References}

Argawijana, et al, Mengukur Tingkat Kualitas Layanan Dan Kepuasan Konsumen Terhadap Loyalitas Pelanggan Pada PT Johar Megah Motor Kota Makassar, dalam Jurnal Ilmu Ekonomi, Vol. 2, No. 1, 2020,h.24-31.

David, Pengaruh E-Service Quality Terhadap Loyalitas Pelanggan Melalui Kepuasan Pelanggan Pada Transportasi Online Grab, dalam Jurnal AGORA, Vol.6, No.2, 2018.

Eisingerich, Andreas B. dan Gaia Rubera, Drivers of Brand Commitment: A Cross National Investigation, dalam Journal of International Marketing, Vol. 18, No.2, 2010.

Fandy Tjiptono dan Gregorius Chandra, Service, Quality and Satisfaction, Edisi 3. (Yogyakarta: Andi, 2011),h, 164.

Fandy, Tjiptono, Service Quality \& Satisfaction, (Yogyakarta: ANDI,2016),h.59.

Griffin, Jill, Customer Loyality Menumbuhkan dan Mempertahankan Kesetiaan Pelanggan, (Jakarta: Erlangga,2010),h.30

Harahap, I., Nasution, Y.S.J., and Chairina. (2021). Analysis of Muslim Customer Loyalty Shopping for Fashion in the Traditional Inpres I Market in Kisaran. Budapest International Research and Critics Institute-Journal (BIRCI-Journal) Vol 4 (1): 28-38.

Hurriyati, Ratih, Bauran Pemasaran dan Loyalitas Konsumen, Bandung: Alfabeta, 2010.

I Gusti Ngurah dan Luh Komang, Pengaruh Brand Image Dan E-Service Quality Terhadap Customer Satisfaction Serta Loyalitas Pengguna Aplikasi Gojek Di Tabanan, dalam Jurnal JAMMS, Vo. 1, No. 1, 2019, h.39-48.

Kotler, P., dan Keller,K.L., Manajemen Pemasaran, Edisi 12,(Jakarta:Erlangga, 2012

Kusumadewi, R.N., Karyono, O. (2019). Impact of Service Quality and Service Innovations on Competitive Advantage in Retailing. Budapest International Research and Critics Institute-Journal (BIRCI-Journal) Vol 2, (2): 366-374.

Lupiyoadi,R , Manajemen Pemasaran Jasa, (Jakarta: Salemba Empat,Edisi 3, 2013),h. 232

Napitupulu, D., Model Keberhasilan Implementasi E-Services (Sistem Layanan Berbasis Elektronik) di Indonesia Studi Kasus: Pemerintah Kota X, Forum Tahunan Iptek dan Inovasi Nasional VI, Forum Iptekin: 2016, h.479-487.

Nawangsari, Sri dan Nadea Dwirahma Putri, Pengaruh E-Service Quality Dan E-Trust Terhadap Kepuasan Nasabah Pengguna BNI Mobile Banking Melalui Citra Bank Sebagai Variabel Intervening (Studi Kasus Pada Nasabah Pengguna BNI Mobile Banking Di Kota Depok), dalam Jurnal Ilmiah Matrik, Vol. 20, No.1, 2020.

Nurastuti, W, Teknologi Perbankan, (Yogyakarta: Graha Imu, 2011).

PT Bank Syariah Mandiri, Memperkuat Daya Saing Melalui Peningkatan Keunggulan Perusahaan, Laporan Tahunan 2018, diunduh pada tanggal 20 Februari 2020. 
Rizal Zulkarnain, et. al, Pengaruh Kualitas Pelayanan Dan Kualitas Produk Terhadap Loyalitas Nasabah Dengan Kepuasan Nasabah Sebagai Variabel Intervening (Studi Kasus Pada PT Bank Syariah Mu'amalah Cilegon), dalam Jurnal Manajemen Dan Bisnis, 2020,h.1-24.

Romadhan, Rakhmat, et. al, E-Service Quality Kepuasan Konsumen Melalui E-Commerce Terhadap Loyalitas Konsumen, dalam Jurnal GeoEkonomi, Vol. 10, No. 2, 2019,h.150163.

Swaid, S. I., \& Wigand, R. T, Measuring The Quality of E-Service: Scale Development and Intitial Validation, dalam Journal of Electronic Commerce Research, Vol.10, No.1, 2009,h.175-195.

Welta, Fretty, Pengaruh Kualitas Layanan dan Kepercayaan terhadap Loyalitas Nasabah pada BMT Surya Barokah, dalam Jurnal I-Economic, Vol 3. No. 2, 2017,h.129-148. 